CARDOSO, AII; SILVA PNL; COLOMBARI, LF; LANNA, NBL; FERNANDES, DM. 2019. Phosphorus sources associated with organic compound in broccoli production and soil chemical attributes. Horticultura Brasileira 37: 228-233. DOI - http://dx.doi.org/10.1590/S0102-053620190215

\title{
Phosphorus sources associated with organic compound in broccoli production and soil chemical attributes
}

\author{
Antonio Ismael Inácio Cardoso ${ }^{1} \mathbb{D}$; Priscilla Nátaly de L Silva ${ }^{1} \mathbb{D}$; Lidiane F Colombari ${ }^{1} \mathbb{D}$; Natália BL \\ Lanna ${ }^{1} \mathbb{D}$; Dirceu M Fernandes ${ }^{1} \mathbb{D}$
}

${ }^{1}$ Universidade Estadual Paulista (UNESP), Botucatu-SP, Brazil; antonio-ismael.cardoso@unesp.br; priscilla_nataly@hotmail.com; colombarifl@yahoo.com.br; nataliabllanna@gmail.com; dirceu.fernandes@unesp.br

\begin{abstract}
Phosphorus is a finite natural resource and the use of gradualrelease phosphate sources, associated with an organic compound may favor a more rational use of this nutrient, since organic matter protects $P$ from soil fixation. The aim of this study was to evaluate the effect of phosphorus sources application, associated with organic compound at planting, on single inflorescence type broccoli production and soil chemical properties at the end of the cycle. Eight treatments were evaluated, in a $4 \times 2$ factorial scheme, using four phosphorus sources [thermophosphate (TM), natural phosphate (NP), reactive natural phosphate (RNP) and triple superphosphate (TSP)]; in the presence $\left(55 \mathrm{t} \mathrm{ha}^{-1}\right)$ and absence of organic compound Visafértil ${ }^{\mathbb{B}}$ at planting. The experimental design was randomized blocks, with four replicates. TSP source presented higher P contents. TM source showed, in the absence of organic compound, higher $\mathrm{pH}$ and contents of organic matter, $\mathrm{Ca}, \mathrm{Mg}, \mathrm{SB}$ and $\mathrm{V} \%$. In the presence of organic compound, NP source provided higher contents of organic matter and $\mathrm{K}$. The addition of organic compound increased $\mathrm{pH}$ and resulted in higher contents of $\mathrm{P}, \mathrm{K}, \mathrm{Ca}, \mathrm{SB}, \mathrm{CEC}$ and $\mathrm{V} \%$. The presence of organic compound favored higher productivity for the sources TM, NP and TSP. Among these sources, TSP provided the highest production both in the presence or absence of organic compound, considering that NP source was the only one which did not differ from TSP for inflorescence fresh weight and productivity, both in the presence and in the absence of organic compound. We concluded that TSP and NP are the best $\mathrm{P}$ sources, associated with the application of organic compound.
\end{abstract}

Keywords: Brassica oleracea var. italica, phosphate fertilization, organic matter, productivity.

\section{RESUMO}

Fontes de fósforo associadas ao composto orgânico na produção de brócolis e atributos químicos do solo

O fósforo é um recurso natural finito e o uso de fontes fosfatadas de liberação gradual associado ao composto orgânico pode favorecer o uso mais racional, devido à matéria orgânica proteger esse nutriente da fixação no solo. Dessa forma, objetivou-se com este trabalho avaliar o efeito de fontes de fósforo associadas à aplicação de composto orgânico no plantio, sobre a produção de brócolis do tipo inflorescência única e as características químicas do solo ao final do ciclo. Foram avaliados oito tratamentos, em esquema fatorial $4 \times 2$, sendo quatro fontes de fósforo [termofosfato (TM), fosfato natural (NP), fosfato natural reativo (RNP) e superfosfato triplo (TSP)]; na presença $\left(55 \mathrm{t} \mathrm{ha}^{-1}\right)$ e ausência de composto orgânico Visafértil ${ }^{\mathbb{R}}$ no plantio, no delineamento em blocos ao acaso, com quatro repetições. A fonte TSP resultou em maiores teores de P. Na ausência do composto orgânico, a fonte TM resultou em maior $\mathrm{pH}$ e teores de $\mathrm{MO}, \mathrm{Ca}, \mathrm{Mg}$, SB e V\%. Na presença do composto orgânico a fonte $\mathrm{NP}$ proporcionou maiores teores de $\mathrm{MO}$ e K. A adição de composto orgânico aumentou o pH e resultou em maiores teores de $\mathrm{P}, \mathrm{K}, \mathrm{Ca}$, $\mathrm{SB}, \mathrm{CTC}$ e V\%. A presença de composto orgânico resultou em maior produtividade para as fontes TM, NP e TSP. Dentre as fontes, o TSP proporcionou maior produtividade tanto na presença como na ausência do composto orgânico, sendo que a fonte NP foi a única que não diferiu do TSP para a massa fresca da inflorescência e produtividade tanto na presença como na ausência de composto orgânico. Conclui-se que as melhores fontes de fósforo foram o TSP e o NP, associados à aplicação de composto orgânico.

Palavras-chave: Brassica oleracea var. italica, adubação fosfatada, matéria orgânica, produtividade.

\section{Received on August 16, 2018; accepted on April 26, 2019}

$\mathrm{B}$ roccoli belongs to Brassicaceae family, and is considered a superfood, due to its nutritional, antioxidant and anticancer properties (Vieira, 2017). The supply of this vegetable on supermarkets has increased and broccoli can be found fresh, frozen or minimally processed. Brazil is the South-American largest broccoli producer with $48 \%$ of the total vegetable cultivation (Tagushi, 2017), considering that in 2016, the production reached about 2.8 million tons (IEA, 2016).

In Brazil, studies on phosphate fertilization for broccoli cultivation are scarce, being this nutrient fundamental for inflorescence growth (Islam et al., 2010). Phosphorus plays an important role in photosynthesis, respiration, energy storage and transfer, cell division and other processes in plants. Although having several functions in plants, phosphorus availability in Brazilian soils is low (Novais \& Smyth, 1999), being this nutrient, commonly, applied in the greatest quantity. Since P is a natural and finite resource, optimization of its use becomes necessary for a more sustainable agriculture.

Phosphate from rocks, 
hyperphosphates and thermophosphates are some $\mathrm{P}$ sources allowed for organic cultivation (Brazil, 2014), which can also be used in conventional cropping. These sources present a slower P dissolution in relation to soluble phosphate sources, giving immediate and/or residual effect on subsequent crops (Novais et al., 2007). Phosphate from rocks, also known as natural phosphates, varies in relation to their origin. The rocks can be volcanic or sedimentary, with ionic isomorphic substitution. Imported phosphates of sedimentary origin are more soluble than Brazilian natural phosphates, since they present lower crystallization and higher reactivity in soil and, therefore, are called reactive natural phosphates (Novais et al., 2007). Thermophosphates result from the thermal treatment of phosphate rocks with or without the addition of other material, and they can be used to neutralize soil acidity, in lower $P$ adsorption (in the presence of silicate), providing $\mathrm{Ca}$ and $\mathrm{Mg}$, among other benefits (Raij, 1991). In conventional cultivation, triple superphosphate is the most commonly used fertilizer, since its dissolution in soil is fast, favoring immediate use by the plant.

Brassicas show good response to organic fertilization (Magro et al., 2010; Candian et al., 2015; Melo, 2015; Corrêa et al., 2016), which avoids phosphorus exposition to soil fixation mechanisms (Kiehl, 2010). According to Fink et al. (2016), in highly weathered soils, organic matter is one of the constituents of the soil that most affects phosphorus desorption and adsorption. In addition, the presence of organic matter improves soil physical and chemical properties and increases microbial life. Organic fertilization favors soil in several senses, improving its structure, aeration and infiltration of water, favors water retention and nutrient uptake and reduces soil losses (Souza \& Resende, 2014). According to Cardoso et al. (2011), soil organic matter might present an effect similar to that of liming, in acidity correction and neutralization of aluminum toxicity. Organic fertilizers provide plant nutrients more slowly than inorganic fertilizers, considering that the release rate depends on several factors, such as the source of applied organic material (Monsalve et al., 2017). In tropical soils, organic fertilization practices become necessary, since its degradation becomes faster due to inclement weather (Villas Bôas et al., 2004).

$P$ content in organic fertilizers is normally low and an addition of this nutrient may favor the development and productivity of crops. Studies on association of organic fertilizers with sources of phosphorus are scarce. Viana \& Vasconcelos (2008) evaluated the efficiency of different thermophosphate proportions, chicken litter and bovine manure and their interactions in lettuce production and verified that addition of phosphorus in chicken litter and bovine manure provided an increase in production of $64.9 \%$ and $23.5 \%$, respectively. No study on a possible influence of phosphorus sources associated with organic compound, as well as isolated effect of phosphorus sources on broccoli cultivation, was found.

Given the above, the aim of this study was to evaluate the effect of phosphorus sources associated to application of organic compound in broccoli production and soil chemical traits at the end of cultivation.

\section{MATERIAL AND METHODS}

The experiment was carried out under field conditions, at São Manuel Experimental Farm, located in the municipality of São Manuel-SP (2246'28' S, 48 34'37'"W, $740 \mathrm{~m}$ altitude), at Universidade Estadual Paulista, campus Botucatu-SP. The local climate is Cfa (Temperate Mesothermal), according to Köppen's international classification. Average, minimum and maximum temperatures during the experiment were $17.9 ; 11.6$ and $24.2^{\circ} \mathrm{C}$, respectively.

The soil of the experimental area was classified as typic distrophic Red Latosol, sandy texture. Chemical analysis $(0-20 \mathrm{~cm})$ showed: $\mathrm{pH}\left(\mathrm{CaCl}_{2}\right)=$ 5.4; Organic matter $=7 \mathrm{~g} \mathrm{dm}^{-3} ; \mathrm{P}_{\text {resina }}=21$ $\mathrm{mg} \mathrm{dm}{ }^{-3} ; \mathrm{H}+\mathrm{Al}=15 \mathrm{mmol}_{\mathrm{c}} \mathrm{dm}^{-3} ; \mathrm{K}=1.0$ $\mathrm{mmol}_{\mathrm{c}} \mathrm{dm}^{-3} ; \mathrm{Ca}=12 \mathrm{mmol}_{\mathrm{c}} \mathrm{dm}^{-3} ; \mathrm{Mg}=$
$11 \mathrm{mmol} \mathrm{dm}^{-3}$; sum of bases $(\mathrm{SB})=24$ $\mathrm{mmol}_{\mathrm{c}} \mathrm{dm}^{-3} ; \mathrm{CEC}=40 \mathrm{mmol}_{\mathrm{c}} \mathrm{dm}^{-3} ;$ base saturation $(\mathrm{V} \%)=61$ and $\mathrm{B}=0.12 \mathrm{mg}$ $\mathrm{dm}^{-3}$. Phosphorus content in soil was classified as low (Trani et al., 1997), showing possible responses to $\mathrm{P}$ source application at planting.

Randomized block design, in a factorial scheme $4 \times 2$, with four replicates was used. Eight treatments were evaluated: thermophosphate (TM), natural phosphate (NP), reactive natural phosphate (RNP) and triple superphosphate (TSP); in presence (55 $t \mathrm{ta}^{-1}$ ) and absence of organic compound at planting date. The dose of organic compound used in this experiment corresponded to the average interval recommended by Trani et al. (1997) and dose of phosphorus $\left(600 \mathrm{~kg} \mathrm{ha}^{-1} \mathrm{P}_{2} \mathrm{O}_{5}\right)$ was the recommended by these authors for broccoli, considering the P contents.

The phosphorus sources used in this study were evaluated and presented the following results: thermophosphate Yoorin $^{\circledR}: 16 \% \mathrm{P}_{2} \mathrm{O}_{5}$, soluble in $2 \%$ citric acid in a ratio $1: 100,17.5 \%$ of total $\mathrm{P}_{2} \mathrm{O}_{5}, 18 \%$ calcium, $7 \%$ magnesium, $0.1 \%$ boron, $0.05 \%$ copper, $0.15 \%$ manganese, $0.55 \%$ zinc and $10 \% \mathrm{Si}$; Biorin Nutrisafra ${ }^{\circledR}$ natural phosphate: $13 \%$ organic matter, $40 \%$ filter cake, $1.8 \% \mathrm{~N}, 13.2 \% \mathrm{P}_{2} \mathrm{O}_{5}, 0.8 \% \mathrm{~K}_{2} \mathrm{O}, 12.4 \%$ $\mathrm{Ca}, 0.3 \% \mathrm{Mg}, 1.4 \% \mathrm{~S}$ and $93,3128,826$, 46963, 4208, $5313 \mathrm{mg} \mathrm{kg}^{-1}$ of B, Na, Cu, $\mathrm{Fe}, \mathrm{Mn}$ and $\mathrm{Zn}$, respectively; reactive natural phosphate Djebel Onk - Algeria: $10 \% \mathrm{P}_{2} \mathrm{O}_{5}$ soluble in $2 \%$ citric acid in a ratio $1: 100$ and $29 \%$ total $\mathrm{P}_{2} \mathrm{O}_{5}$ and $35 \%$ $\mathrm{Ca}$; triple superphosphate: $41 \% \mathrm{P}_{2} \mathrm{O}_{5}$ soluble in ammonium citrate (CNA) + water, $36 \%$ water-soluble $\mathrm{P}_{2} \mathrm{O}_{5}$ and $10 \% \mathrm{Ca}$.

The authors used Visafértil ${ }^{\circledR}$ organic compound, which consists of bovine manure and chicken litter, bran and cake of vegetable origin, pinus/eucalyptus bark and ashes. Chemical analysis of the compound showed $\mathrm{pH} 7.5, \mathrm{C}: \mathrm{N}$ ratio $4 / 1$, organic matter $=30 \%$; humidity $=$ $7 \% ; \mathrm{C}=17 \% ; \mathrm{N}=1.4 \% ; \mathrm{P}_{2} \mathrm{O}_{5}=1.6 \%$; $\mathrm{K}_{2} \mathrm{O}=1.4 \% ; \mathrm{Ca}=10.4 \% ; \mathrm{Mg}=1.1 \% ; \mathrm{S}=$ $0.7 \%$ and $222 ; 5134 ; 324 ; 17345 ; 910$ and $177 \mathrm{mg} \mathrm{kg}^{-1}$ of $\mathrm{B}, \mathrm{Na}, \mathrm{Cu}, \mathrm{Fe}, \mathrm{Mn}$ and $\mathrm{Zn}$, respectively.

Liming was performed on March 4, 2016 (77 days before seedling 
transplanting), to raise base saturation value to $80 \%$, recommended for broccoli crop (Trani et al., 1997; Melo, 2015). All fertilizers used during planting fertilization, including phosphorus sources and organic compound, were broadcasted and incorporated with a plow. In the treatments using TM, NP and RNP sources, $\mathrm{N}$ was made available by castor bean cake $(1.36 \mathrm{t}$ $\left.\mathrm{ha}^{-1}\right)$ and $\mathrm{K}$ by potassium sulfate $(0.48 \mathrm{t}$ $\left.\mathrm{ha}^{-1}\right)$, allowed sources in organic system (Brazil, 2014). In TSP source, $0.28 \mathrm{tha}^{-1}$ of ammonium sulfate and $0.4 \mathrm{t} \mathrm{ha}^{-1}$ of potassium chloride were used.

In top-dressing, $2.44 \mathrm{t} \mathrm{ha}^{-1}$ castor bean cake and $0.18 \mathrm{t} \mathrm{ha}^{-1}$ potassium sulfate were used in treatments with organic phosphate sources. For inorganic source (TSP), $0.51 \mathrm{t} \mathrm{ha}^{-1}$ ammonium sulfate and $0.15 \mathrm{t} \mathrm{ha}^{-1}$ potassium chloride were used. Top dressing fertilization corresponded to an interval average value recommended by Trani et al. (1997), from 15 to $200 \mathrm{tha}^{-1} \mathrm{~N}$ and 60 to $120 \mathrm{t} \mathrm{ha}^{-1} \mathrm{~K}_{2} \mathrm{O}$. Top dressing fertilization was splitted into four times $(15,30,45$ and 60 days after transplanting).

The authors used hybrid BRO 68, single inflorescence type broccoli, sown on April 25, 2016 in 200-cell polypropylene trays, containing Carolina Soil ${ }^{\circledR}$ substrate. Throughout the cycle, only one application of $1 \mathrm{~g}$ $\mathrm{L}^{-1}$ boric acid was done, five days before seedling transplanting into seedbeds, 24 days after sowing (DAS), when four definitive leaves were formed. We used 26 plants per $4.5 \mathrm{~m}^{2}$ plot and only six plants of the central rows consisted the useful plot. Spacing was $0.4 \mathrm{~m}$ between lines and $0.8 \mathrm{~m}$ between plants. Sprinkler irrigation was used (3 mm/day); spontaneous plants were controlled through manual weeding.

Manual harvesting was held from 94 to 122 DAS, and the following traits were evaluated: inflorescence diameter (cm); inflorescence fresh weight ( $\mathrm{g}$ plant $\left.^{-1}\right)$; estimated productivity ( $\mathrm{t} \mathrm{ha}^{-1}$ ) and average production cycle (DAS).

At the end of the experiment, simple samples of soil were collected (0-20 $\mathrm{cm}$ ), in five points, randomly, in order to obtain a composed sample per plot. These samples were taken to the Soil Fertility Laboratory of Department of Soil and Environmental Resources in order to determine the available macronutrient contents, as well as $\mathrm{pH}$, organic matter content, potential acidity, sum of bases, cation exchange capacity and base saturation (V\%) (Raij et al., 2001).

Data were submitted to analysis of variance and Tukey test $(\mathrm{p}<0.05)$ was used to compare averages. Statistical software Sisvar (Ferreira, 2011) was used.

\section{RESULTS AND DISCUSSION}

Interaction among phosphorus sources in the presence and absence of organic matter was significant for inflorescence fresh weight, estimated productivity and cycle. For diameter, no difference among treatments was noticed and values obtained in the treatments, 13.9 to $14.6 \mathrm{~cm}$ (Table 1), were within the range considered optimal for fresh market, from 12 to $15 \mathrm{~cm}$ (Melo, 2015). However, higher inflorescence fresh weight and productivity were obtained in the presence of organic compound, in comparison to the absence of organic compound, for most sources (TM, NP and TSP), except for RNP (Table 1). Diniz et al. (2008) also reported an increase in broccoli production using organic compound. Ferreira et al. (2013) obtained higher diameter, inflorescence fresh weight and productivity of American broccoli using "Bokashi" compost. Corrêa et al. (2016), evaluating doses of sulfur as top dressing, in the presence and absence of organic compounds at planting, verified that the presence of organic compound resulted in higher inflorescence fresh weight and diameter.

Broccoli, as well as other brassicas, is among the crops which the most respond to organic fertilization (Magro et al., 2010; Candian et al., 2015). Organic compounds have gradual availability reducing losses and avoiding the limitation in plant development. Besides promoting greater fertility and stimulating the development of beneficial microorganisms, they improve soil physical characteristics, acting as a conditioner (Souza \& Resende, 2014).

For inflorescence fresh weight and estimated productivity, TSP source did not show any difference from TM and NP sources, being superior only the RNP source in the presence of organic compound and TM and RNP sources in the absence of organic compound (Table 1). Fresh consumer market shows preference to 300 to 400 $\mathrm{g}$ inflorescences (Melo, 2015), values obtained in all sources with presence of organic compound $(327,357,303$ and

Table 1. Diameter and inflorescence fresh weight (IFW), productivity (PRO) and cycle of broccoli plants, related to phosphorus sources in the presence (P) and absence (A) of organic compound. São Manuel, UNESP, 2016.

\begin{tabular}{|c|c|c|c|c|c|c|c|c|}
\hline \multirow{2}{*}{ P sources } & \multicolumn{2}{|c|}{ Diameter (cm) } & \multicolumn{2}{|c|}{ IFW (g/plant) } & \multicolumn{2}{|c|}{ Productivity (t/ha) } & \multicolumn{2}{|c|}{ Cycle (DAS) } \\
\hline & $\mathbf{P}$ & $\mathbf{A}$ & $\mathbf{P}$ & $\mathbf{A}$ & $\mathbf{P}$ & $\mathbf{A}$ & $\mathbf{P}$ & $\mathbf{A}$ \\
\hline TM & $14.4 \mathrm{Aa}$ & $14.6 \mathrm{Aa}$ & $327 \mathrm{Aab}$ & $271 \mathrm{Bb}$ & 10.2Aab & $8.4 \mathrm{Bb}$ & $106 \mathrm{Aab}$ & $109 \mathrm{Abc}$ \\
\hline NP & $14.5 \mathrm{Aa}$ & $14.5 \mathrm{Aa}$ & 357Aab & $282 \mathrm{Bab}$ & 11.1Aab & $8.8 \mathrm{Bab}$ & $100 \mathrm{Aa}$ & $103 \mathrm{Aab}$ \\
\hline RNP & 13.9Aa & $14.4 \mathrm{Aa}$ & $303 \mathrm{Ab}$ & $268 \mathrm{Ab}$ & $9.4 \mathrm{Ab}$ & $8.3 \mathrm{Ab}$ & $111 \mathrm{Ab}$ & $113 \mathrm{Ac}$ \\
\hline TSP & $14.1 \mathrm{Aa}$ & $14.0 \mathrm{Aa}$ & $377 \mathrm{Aa}$ & $332 \mathrm{Ba}$ & $11.7 \mathrm{Aa}$ & $10.3 \mathrm{Ba}$ & $98 \mathrm{Aa}$ & 99Aa \\
\hline CV $(\%)$ & \multicolumn{2}{|c|}{3.16} & \multicolumn{2}{|c|}{8.90} & \multicolumn{2}{|c|}{8.90} & \multicolumn{2}{|c|}{8.90} \\
\hline
\end{tabular}

Averages followed by the same letter, uppercase in lines and lowercase in columns, do not differ from each other, by Tukey test at $5 \%$ probability; $\mathrm{TM}=$ thermophosphate; $\mathrm{NP}=$ natural phosphate, $\mathrm{RNP}=$ reactive natural phosphate; $\mathrm{TSP}=$ triple superphosphate; $\mathrm{DAS}=$ days after sowing. 
377 g plant $^{-1}$ with TM, NP, RNP and TSP sources, respectively) and only in TSP source (332 $\left.\mathrm{g} \mathrm{plant}^{-1}\right)$ in the absence of the compound. NP organic source was the only one which did not differ from TSP source in relation to productivity, in the presence or absence of organic compound. In relation to RNP source, only the macronutrients $\mathrm{P}$ and $\mathrm{Ca}$ are presented in its composition, although it presents greater solubility when comparing to NP, whereas NP, besides $\mathrm{P}$ and $\mathrm{Ca}$, also presents $\mathrm{N}, \mathrm{K}, \mathrm{Mg}, \mathrm{S}$ and $\mathrm{B}$, important nutrients for broccoli production (Filgueira, 2008; Souza \& Resende, 2012; Melo, 2015; Corrêa et al., 2016).

The presence or absence of organic compound did not affect the cycle (Table 1). TSP, NP and TM sources resulted in shorter cycles in the presence of organic compound and TSP and NP sources in the absence. Reduction in the cycle, without harming production, is advantageous since it provides cost reduction, as the plants need cultural practices, such as phytosanitary control and irrigation, for fewer days. The cycle ranged from 98 to 113 DAS, being in accordance with Melo (2015) who reported that the cycle may vary from 90 to 130 days.
Considering that commercial classification takes into consideration broccoli inflorescence fresh weight, higher response is highlighted with TSP source application in the presence and absence of organic compound. The efficiency of TSP source in the absence of organic compound corroborates the observed by Cecilio Filho et al. (2015) and Islam et al. (2010) who verified significant effects on inflorescence fresh weight, diameter and productivity of broccoli. Adding organic compound at planting together with different $\mathrm{P}$ sources favored greater inflorescences, except for RNP source. Brassicas, such as broccoli, present good response to organic fertilization, with significant gains in productivity (Magro et al., 2010; Candian et al., 2015; Corrêa et al., 2016). Organic compound application, besides the effects on physical and biological quality of the soil, also releases macro and micronutrients in a balanced way, favoring plant development (Kielh, 2010).

Interaction among $\mathrm{P}$ sources was observed, with presence or absence of organic compound for all soil chemical traits evaluated (Table 2).

The use of organic compound at planting provided higher $\mathrm{pH}$ in soil and contents of $\mathrm{P}, \mathrm{K}, \mathrm{Ca}, \mathrm{SB}, \mathrm{CEC}$ and $\mathrm{V} \%$, independent of the $\mathrm{P}$ source applied (Table 2). This result may be related to the fact that organic matter is source of $\mathrm{P}, \mathrm{K}$ and $\mathrm{Ca}$, according to the compound chemical analysis, besides its potential to reduce $P$ fixation (Kiehl, 2010). However, potential acidity $(\mathrm{H}+\mathrm{Al})$ was lower in the presence of organic compound, which can be explained by the organic matter in soil, besides castor bean cake, rich in carbon (average of 35\%), which was used as $\mathrm{N}$ source in topdressing applications only in treatments with $\mathrm{P}$ sources allowed in organic agriculture, which makes aluminum unavailable, corroborating results obtained by Oliveira et al. (2014).

Beneficial effect of organic compound application on soil chemical traits was also found by Cardoso et al. (2011) who observed an increase in content of organic matter, $\mathrm{Ca}, \mathrm{Mg}$, $\mathrm{SB}, \mathrm{CEC}$ and V\%. Magro et al. (2010) reported an increase in content of organic matter and potassium with organic compound application in broccoli seed production, whereas Candian et al. (2015) verified an organic compound effect on $\mathrm{pH}$ and organic matter content; no significant differences were observed

Table 2. Soil chemical characteristics at the end of the experiment, in relation to phosphorus sources in presence (P) and absence (A) of organic compound. São Manuel, UNESP, 2016.

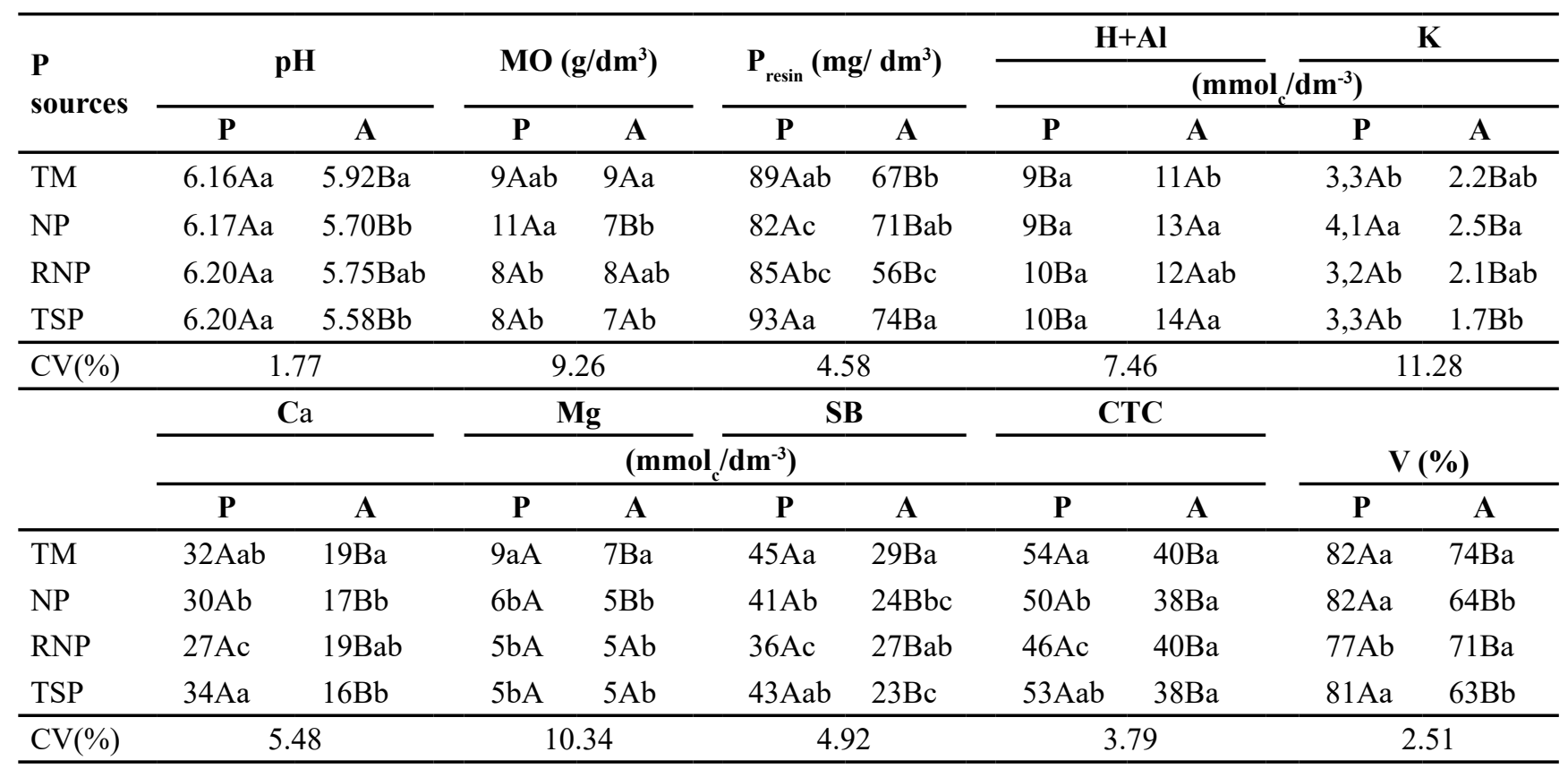

Averages followed by same letters, uppercase in lines and lowercase in columns, do not differ from each other, by Tukey test, $5 \%$. TM= thermophosphate; $\mathrm{NP}=$ natural phosphate, $\mathrm{RNP}=$ reactive natural phosphate; $\mathrm{TSP}=$ triple superphosphate. 
for contents of $\mathrm{P}, \mathrm{Ca}, \mathrm{Mg}, \mathrm{SB}, \mathrm{CEC}$ and $\mathrm{V} \%$ in soil.

In the presence of organic compound, no difference was verified among the sources for soil $\mathrm{pH}$ and in the absence, TM source resulted in higher $\mathrm{pH}$ (Table 2). Value of $\mathrm{pH}$ was about 6 for all tested sources in the presence of organic compound at planting, probably influenced by an increase of $\mathrm{Ca}$ content and increase of $\mathrm{V} \%$. In the absence of organic compound, higher $\mathrm{pH}$ using TM source can be attributed to its power of soil acidity neutralization, due to the presence of silicate $(10 \%$ of $\mathrm{Si}$ ) in its composition. Different result was found by Zoz et al. (2009) who verified and increase in $\mathrm{pH}$ only for soluble phosphorus sources (TSP and microgranulated organomineral phosphate).

Organic matter content was greater in the treatments which NP source was combined with organic compound at planting, and TM source in the absence of the compound (Table 2). Filter cake present in NP source, which is an organomineral NP, probably, favored an increase of organic matter. TSP source provided higher $\mathrm{P}$ content in the presence and absence of organic compound (Table 2), probably because it is the greatest-soluble source. TSP source associated with the organic compound became more efficient in relation to phosphorus availability, reducing the exposure of this nutrient to fixation mechanisms in soil (Kiehl, 2010), favoring plant development.

Potential acidity $(\mathrm{H}+\mathrm{Al})$ in the presence of organic compound at planting did not differ among sources, whereas in the absence of organic compound, NP and TSP sources provided higher acidity (Table 2 ). No effect among sources on the potential acidity in the presence of the compound was noticed, probably due to $\mathrm{pH}$ value being around 6.0 with the application of organic compound and, according to Raij (2011), at this value $\mathrm{Al}^{+3}$ is precipitated, non-exchangeable.

NP source resulted in higher K content, in the presence or absence of organic compound at planting. For $\mathrm{Ca}$ content, TSP source provided higher average in the presence of organic compound, TM and RNP sources in the absence of the compound. For $\mathrm{Mg}$ and SB contents, TM source provided higher value in the presence and absence of organic compound. In the presence of organic compound, TM source resulted in higher CEC and in the absence of the compound, no difference among the sources (38 to $40 \mathrm{mmol}_{\mathrm{c}}$ $\mathrm{dm}^{-3}$ ) was noticed. TM, NP and TSP sources provided higher values in base saturation in the presence of organic compound and, in the absence, the TM and RNP sources (Table 2).

In general, the authors noticed the superiority of TM source in the presence and absence of the organic compound at planting for some soil characteristics, such as content of $\mathrm{Mg}, \mathrm{SB}, \mathrm{CEC}$ and $\mathrm{V} \%$ (Table 2), probably because it is the source with the highest content of $\mathrm{Mg}(7 \%)$ in its composition, resulting in higher SB and V\%. Malavolta (1981) highlights that this higher efficiency is due to the participation of thermophosphate in neutralization of soil acidity, in the supply of $\mathrm{Ca}$, $\mathrm{Mg}$ and micronutrients, in reduction of the manganese toxicity and lower $P$ adsorption due to the presence of silicate in its composition. TM is prepared by melting a mixture of phosphate and serpentine, forming magnesium silicate. The material is cooled and milled until it turns into a fine powder (Raij, 1991). TM source composition probably provided better soil chemical characteristics in the absence of the organic compound, whereas in the presence of the organic compound, the characteristic and mineralization of the nutrients of the organic compound associated with TM source, favored a more gradual release of the nutrients, increasing the efficiency of the fertilizer.

The results obtained in this study allow to conclude that TM source in the absence of organic compound resulted in higher $\mathrm{pH}$ and contents of organic matter, $\mathrm{Ca}, \mathrm{Mg}, \mathrm{SB}$ and $\mathrm{V} \%$. In the presence of organic compound, NP source provided higher contents of organic matter and K, whereas TSP source presented higher $\mathrm{P}$ contents in the presence $\left(93 \mathrm{mg} \mathrm{dm}^{-3}\right)$ and absence $\left(74 \mathrm{mg} \mathrm{dm}^{-3}\right.$ ) of organic compound. Addition of organic compound raised $\mathrm{pH}$ and resulted in higher contents of $\mathrm{P}, \mathrm{K}, \mathrm{Ca}, \mathrm{SB}, \mathrm{CEC}$ and $\mathrm{V} \%$. TSP source provided greater productivity in the presence and absence of organic compound, whereas NP source was the only one which did not differ from TSP for inflorescence fresh weight and productivity both in the presence and absence of organic compound. Thus, using low-soluble $\mathrm{P}$ sources, together with organic fertilization, and obtaining a productivity equivalent when using high-soluble sources, such as TSP, is possible.

Given the above, the authors recommend the use of organic compound to produce broccoli and, as $\mathrm{P}$ source, they recommend the use of TSP or NP, highlighting that, for organic producers, just NP source is recommended.

\section{REFERENCES}

BRASIL. Instrução Normativa $n^{\circ} 17$ de 18 de junho de 2014. Estabelece o Regulamento Técnico para os Sistemas Orgânicos de Produção, bem como as listas de substâncias e práticas permitidas para uso nos Sistemas Orgânicos de Produção. Brasília, June 20, 2014. Seção 1. 22p.

CANDIAN, JC; MARTINS, BNM; CARDOSO, AII. 2015. Doses de composto orgânico no desenvolvimento inicial de couve-flor e nas características químicas do solo. Cultivando o Saber 8: 257-266.

CARDOSO, AII; FERREIRA, KP; VIEIRA JÚNIOR, RM; ALCARDE, C. 2011. Alterações em propriedades do solo adubado com composto orgânico e efeito na qualidade das sementes de alface. Horticultura Brasileira 29: 594-599.

CECÍLIO FILHO, AB; SILVA, GS; CORTEZ, JWM; BARBOSA, JC. 2015. Cauliflower and broccoli productivity as influenced by phosphorus fertilizer doses in a P-rich soil. Australian Journal of Crop Science 9: 709712.

CORRÊA, CV; GOUVEIA, AMS; MARTINS, BNM; TAVARES, AEB; LANNA, NBL; CARDOSO, AII; EVANGELISTA, RM. 2016.Response of broccoli to sulphur application at topdressing in the presence or absence of organic compost at planting. African Journal of Agricultural Research 11: 3287-3292.

DINIZ, ER; SANTOS, RHS; URQUIAGA, SS; PETERNELLI, LA; BARRELLA, TP; FREITAS, GB. 2008. Crescimento e produção de brócolis em sistema orgânico em função de doses de composto. Ciência e Agrotecnologia 32: 1428-1434.

FERREIRA, DF. 2011. Sisvar: a computer statistic analysis system. Ciência e Agrotecnologia 35: 1039-1042.

FERREIRA, S; SOUZA, RJ; GOMES, LAA. 
2013. Produtividade de brócolis de verão com diferentes doses de bokashi. Revista Agrogeoambiental 5: 31-38.

FINK, JR; INDA, AV; TIECHER, T; BARRÓN, V. 2016. Iron oxides and organic matter on soil phosphorus availability. Ciência e Agrotecnologia 40: 369-379.

IEA - Instituto de Economia Agrícola. 2016. Estatística da produção paulista. Avaiable at: http://ciagri.iea.sp.gov.br/nia1/subjetiva. aspx? cod sis=1\&idioma=1. Accessed October 7, 2017.

ISLAM, MH, SHAHEB, MR, RAHMAN, S, AHMED, B, ISLAMAND, ATMT SARKER, PC. 2010. Curd yield and profitability of broccoli as affected by phosphorus and potassium. International Journal Sustainable Crop Production 5: 1-7.

KIEHL, EJ. 2010. Novos fertilizantes orgânicos. Piracicaba, BR: DEGASPARI. 248p.

MAGRO, FO; ARRUDA, N; CASA, J; SALATA, AC; CARDOSO, AII; FERNANDES, DM. 2010. Composto orgânico na produção e qualidade de sementes de brócolis. Ciência e Agrotecnologia 34: 596-602.

MALAVOLTA, E. 1981. Manual de química agrícola: Adubos e adubação. 3. ed. São Paulo: Editora Agronômica Ceres. 596p.
MELO, RAC. 2015. A cultura do brócolis. Brasília: Embrapa. 153p.

MONSALVE, OI; GUTIÉRREZ, JS; CARDONA, WA. 2017. Factores que intervienen em el processo de mineralización de nitrógeno cuando son aplicadas en meiendas orgânicas al suelo.Revista Colombiana de Ciências Horticolas 11: 200-209.

NOVAIS, RF; SMYTH, TJ. 1999. Fósforo em solo e planta em condições tropicais. Viçosa: UFV. 399p.

NOVAIS, RF; ALVAREZ, VVH; BARROS, NF; FONTES, RLF; CANTARUTTI, RB; NEVES, JCL (eds). 2007. Fertilidade do Solo. Viçosa: SBCS. 1017p.

OLIVEIRA, LB; ACCIOLY, AMA; SANTOS, CLR; FLORES, RA; BARBOSA, FS. 2014. Características químicas do solo e produção de biomassa de alface adubada com compostos orgânicos. Revista Brasileira de Engenharia Agrícola Ambiental 18: 157-164.

RAIJ, BV. 1991. Fertilidade do solo e adubação. Piracicaba: Editora Agronômica Ceres. 343p.

RAIJ, BV. 2011. Fertilidade do solo e manejo de nutrientes. Piracicaba: International Plant Nutrition Institute. 420p.

RAIJ, BV; ANDRADE, JC; CANTARELLA, H; QUAGGIO, JA. 2001. Análise química para avaliação da fertilidade de solos tropicais. Campinas: IAC. 285p.

SOUZA, JL; RESENDE, P. 2014. Manual de Horticultura Orgânica. 3. ed. Viçosa: Aprenda Fácil. 841p.

TAGUSHI, V. 2017. Brasil lidera produção de brócolis, mas consumo ainda tem muito a crescer. Available at: http://revistagloborural. globo.com/Noticias/Agricultura/ noticia/2017/08/brasil-lidera-producao-debrocolis-mas-consumo-ainda-tem-muitocrescer.html. Accessed October 8, 2017.

TRANI, PE; PASSOS, FA; AZEVEDO, JA; TAVARES, M. 1997. Brócolos, couve-flor e repolho. In: RAIJ, BV; CANTARELLA, H; QUAGGIO, JA; FURLANI, AMC. Recomendações de adubação e calagem para o Estado de São Paulo. Campinas: IAC, p.175.

VIANA, EM; VASCONCELOS, ACF. 2008. Produção de alface adubada com termofosfato e adubos orgânicos. Revista Ciência Agronômica 39: 217-224.

ZOZ, T; LANA, MC; STEINER, F; FRANDOLOSO, JF; FEY, R. 2009. Influência do $\mathrm{pH}$ do solo e de fertilizantes fosfatados sobre a adsorção de fósforo em Latossolo Vermelho. Synergismus Scyentifica 04: 328330. 